\title{
VASPIN AND CLUSTERIN ROLE IN PATHOGENESIS OF DIABETES MELLITUS IN OBESITY
}

\section{Karachentsev Yu., Kravchun N., Misiura K., Balukh M., Titova Yu.}

Department of Pharmacotherapy of Endocrine Diseases, State Institution "V. Danilevsky Institute for endocrine pathology problems National Academy of Medical sciences of Ukraine", Kharkiv, Ukraine

Inflammation of adipose tissue while its extra accumulation is an important constituent of pathogenesis of type 2 diabetes mellitus in obese patients. Vaspin is a binding adipokine between the development of systemic low intensity inflammation and modulation of insulin effects at tissue level. Serum clusterin level serves a marker of systemic inflammation in the body.

\section{OBJECTIVE}

: to determine circulating vaspin and clusterin contents depending on the degree of adipose tissue accumulation, blood insulin level, HOMA index in obese subjects.

\section{MATERIAL AND METHODS}

250 individuals aged $(65.48 \pm 11.86)$ year were observed; adipose tissue mass, including relative parameters with reference to total body mass, was assessed by bioimpedance analysis; circulation vaspin and clusterin contents were determined by enzyme immunoassay; HOMA insulin resistance index was determined.

RESULTS

$\begin{aligned} & \text { Blood vaspin and } \\ & \text { clusterin levels } \\ & \text { intercorrelate positively } \\ & (r=0.871, p<0.001) \text {. }\end{aligned}$

Blood vaspin level correlates positively with adipose body mass $(r=0.5582,(p<0.001))$; with insulinemia level and HOMA index: $(r=0.7944(p<0.001)$, and $r=0.7720$ $(p<0.001))$.

Blood vaspin level $(\mathrm{ng} / \mathrm{mL})=$ [340.4788 + 8.2557* adipose mass].

[254.1396 + 19.2453* insulin contents in blood] [287.6995 + 73.0490* HOMA index].

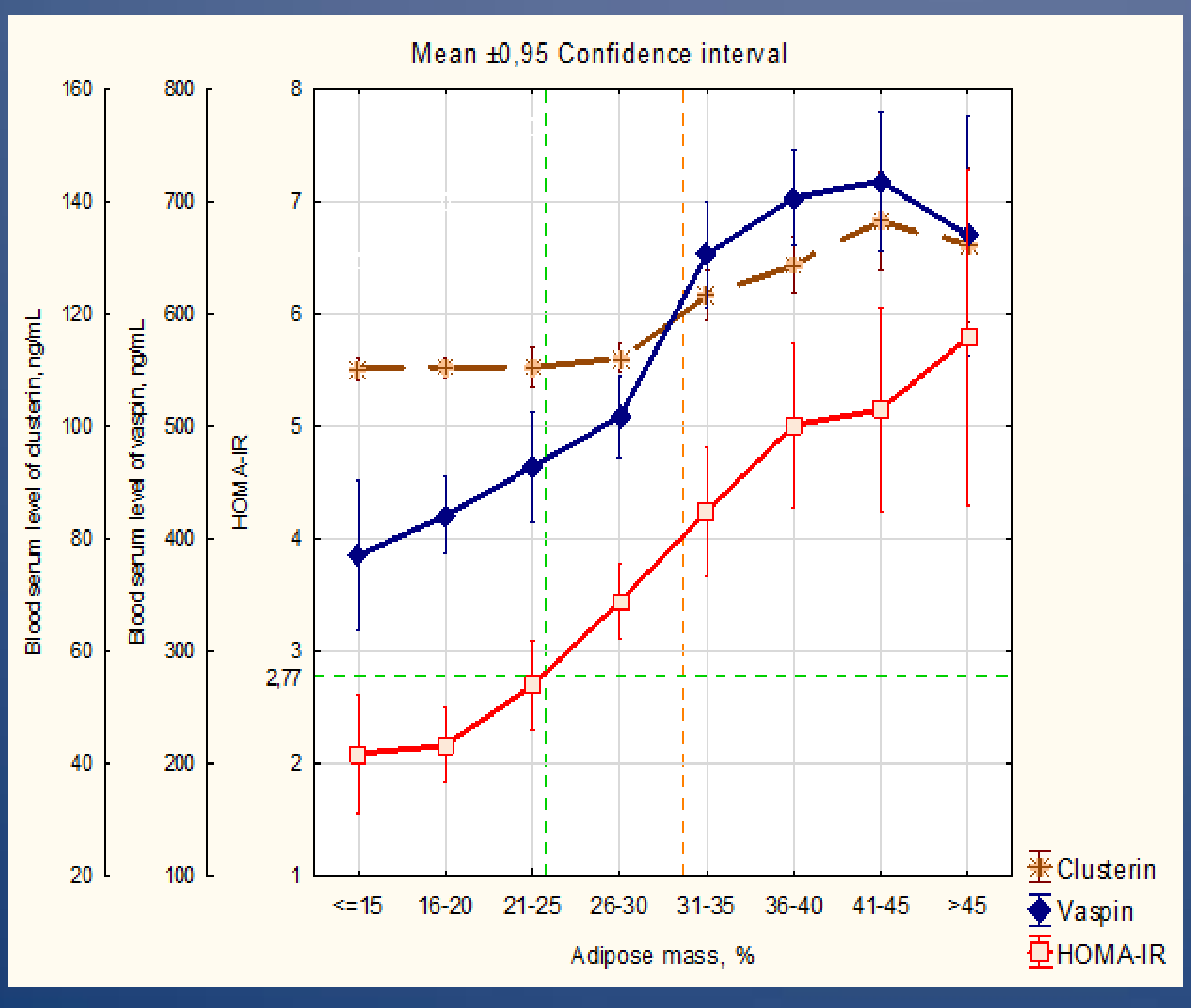

Accumulation of adipose mass over $25 \%$ of total body mass $\rightarrow$

Increased levels of

- clusterin - from $100 \mathrm{ng} / \mathrm{mL}$ and higher;

- of vaspin from $460 \mathrm{ng} / \mathrm{mL}$ and over;

- HOMA index > 2.77.

Accumulation of adipose tissue more than $34 \% \rightarrow>$

- HOMA index > 4.00;

- Increased levels of blood clusterin from $120 \mathrm{ng} / \mathrm{mL}$ and over; of blood vaspin from $650 \mathrm{ng} / \mathrm{mL}$ and over.

\section{CONCLUSIONS}

1. Vaspin and clusterin influence in pathogenesis of diabetes mellitus in obesity was proved. 2. Correlation between accumulation of adipose tissue, changes in its endocrine function, reduced insulin sensitivity of the body, and possible development of diabetes mellitus has been established. 